\title{
Post-imperial and Post-war
}

\section{Violence in the South Slav}

\section{Lands, I9I7-I923}

\section{JOHN PAUL NEWMAN}

\begin{abstract}
This article looks at the transition of the Habsburg South Slav lands, in particular Croatia, from empire into (Yugoslav) nation-state from 1917 to 1923, and the violence which attended it. While this transition was less cataclysmic in the South Slav lands than in other parts of the former Habsburg Empire, patterns of paramilitary violence and counter-revolution similar to those elsewhere in Europe were also present here. The article looks at these patterns from a transnational perspective and shows that although state control was effectively restored in Croatia by 1923, paramilitary networks forged during 1917-23 would return as Yugoslavia faced greater external threats and internal disequilibrium in the 1930 s.
\end{abstract}

The Croatian author Miroslav Krleža wrote at the end of I9I 8 in the Croatian capital, Zagreb, of his surprise at the rapidity of the Dual Monarchy's demise: 'A few days ago Austria [sic] disappeared from our little town so nonchalantly that not one of our many dear, respectable fellow-townspeople noticed that, in fact, among us, Austria was no more. ${ }^{1}$ Certainly the fall of the house of Habsburg was less apocalyptic in the South Slav lands than in Austria itself, and post-imperial Croatia did not convulse in revolution and violent counter-revolution as did Hungary. But neither was the transition out of Austria-Hungary and into the Kingdom of Serbs, Croats and Slovenes (hereafter Yugoslavia) as seamless or as pacific as Krleža suggested. In fact, the breakdown of imperial authority over the course of I9I 8 allowed for - and was accelerated by - a state of apparent lawlessness in much of the Croatian hinterland, as so-called 'Green Cadres' attacked the property of large landholders and refused to go on contributing to the monarchy's war effort. Attached to the Green Cadres were

School of History and Archives, Newman Building, University College Dublin, Belfield Campus, Dublin 4, Ireland; johnpaul.newman@ucd.ie. All translations of quotations from untranslated sources are by the author.

1 Miroslav Krleža, 'Pijana novembarska noč I9i 8', in Dnevnik 1918-1922: Davni dani II (Zagreb: Zora, I977), I46. 
arguably more politicised groups of 'returnees' from revolutionary Russia, South Slav soldiers who hoped to restage the Bolshevik revolution in the Habsburg lands of central Europe. This unrest was in large part instigated and maintained by rank-andfile South Slav soldiers of the Habsburg army, mainly peasant conscripts. However, a smaller number of ex-Habsburg officers also saw this period of transition as an opportunity to effect their own kind of revolution, similar in conception to those in counter-revolutionary Hungary and Germany.

In order to understand fully the process of transition from empire to (Yugoslav) nation-state and the violence which attended this process, it is necessary to look beyond national boundaries and to consider this transition in a more general context. Collapse of empire, revolution and counter-revolution were European-wide phenomena during I9I 7-23, and they provided transnational networks, programmes and ideologies for the groups considered below. As the revolutionary moment peaked and then subsided in Europe, the efficacy of these groups also diminished, and was ultimately circumscribed by a number of local factors. These included the military superiority of the Serbian/Yugoslav army and the (short-term, at least) success of this institution in integrating former Habsburg soldiers into its officer corps, the effective policing of radical movements in Yugoslavia, and the mass popularity of a pacifist, anti-militarist agrarian movement among Croats after i9i 8. Nevertheless, this article will show that the violence of I9I7-I923 would resurface, mutatis mutandis, as Serb-Croat relations worsened in the I930s. In order to understand that period it is necessary to look at the violence, both actual and potential, of I9I7-23. This violence grew out of the First World War, and is closely connected to the experience of South Slav soldiers in Habsburg uniform, the changing fortunes of the monarchy's war effort, and the changing attitudes of its South Slav soldiers.

\section{Habsburg South Slavs during the war}

From the outset of the war, Habsburg authorities seem to have been satisfied that Croats, at least, would fight loyally and willingly for the monarchy. Although imperial authorities had been concerned about the increasing attraction of the movement for South Slav unification for the youth of Croatia, Dalmatia, and Bosnia and Herzegovina, especially following the impressive victories of the Kingdom of Serbia in the first and second Balkan wars, ${ }^{2}$ they were also relieved when the news of the assassination of Archduke Franz Ferdinand in Sarajevo in June I9I4 led to anti-Serb riots and violence in a number of cities in Croatia and Bosnia. ${ }^{3}$

Once in Habsburg uniform, the experience of South Slavs was varied. Somewhat paradoxically, the theatre in which South Slav soldiers experienced the fiercest fighting, the Italian front, was also the theatre where they seem to have fought with

2 Mirjana Gross, 'Nacionalne ideje studentske omladine u Hrvatskoj uoći svetskog rata', Historijski zbornik, XXI-XXII (I969), 75-I43.

3 Robert J. Donia, Sarajevo: A Biography (London: Hurst: 2006), I23-6, and Andrej Mitrović, Serbia's Great War 1914-1918 (London: Hurst: 2007), I I-23. 
most determination. ${ }^{4}$ With the notable exception of the Slovene officer Ljudevit Pivko and his co-ordinated desertion to the Italians and subsequent pro-Entente propaganda work, South Slav soldiers - especially Croats and Slovenes - fought well until the very end of the war, apparently concerned with defending their hearth from widely known Italian territorial claims. ${ }^{5}$

The situation was more complicated on the Balkan front. Distinctions between the South Slav nationalities were of particular consequence for Austria-Hungary here, especially in ethnically heterogeneous areas such as Bosnia and Herzegovina. As in Croatia, Austro-Hungarian authorities concluded that the biggest threat to their authority came from ethnic Serbs. The governor-general of occupied Bosnia and Herzegovina (and Dalmatia) from November I9I4 onwards, the Croat officer Stjepan Sarkotic, saw no contradiction between working on behalf of the monarchy and Croatian national interest in this region. Sarkotic, like a number of high-ranking Habsburg officers as well as an opposition party in the Croatian Sabor (Assembly) known as the 'Frankists', hoped that by fighting loyally for the Habsburgs during the war, Croats would be rewarded in a putative post-war reorganisation of the monarchy. Sarkotic oversaw surveillance and punitive measures whose intention was to break the Serbian nationalist movement, ensuring its unproblematic incorporation into the monarchy after the war.

The implementation of this policy involved internment, mainly of ethnic Serbs, but also of anti-monarchy Muslims and Croats, the organisation of paramilitary units known as the Schutzkorps, comprising mainly Muslims, and trials of Serbian political, cultural and ecclesiastical elites, culminating in the so-called 'Banja Luka Trials'. Sarkotić's hostility to Serbian nationalism and his dual loyalty - to both Habsburg and Croatian causes - are illustrative of the attitudes of a small section of the Croatian elite within the monarchy, mainly Habsburg officers and pro-Habsburg 'Frankist' deputies in the Croatian wartime Sabor. They would come to play an important role in attempts at counter-revolution during I9I7-23.

In terms of understanding the 'aftershocks', violence and lack of order during I9I7-I923, the Eastern Front is key. For a large number of soldiers on this front the war was over by June I9I6, when the success of the summer offensive of the Russian general Alexei Brusilov resulted in the loss of almost a third of the Austro-Hungarian army in the east, or 750,000 soldiers, including 380,000 prisoners of war. ${ }^{7}$ Ivo Banac has calculated that of the 200,000 South Slav soldiers in Russian captivity over the

${ }^{4}$ See, e.g., Richard B. Spence, 'No troops displayed greater martial ardour against Italy than the Yugoslavs', in 'Yugoslavs, the Austro-Hungarian Army, and the First World War', doctoral dissertation, University of California Santa Barbara, I98 I, 95.

5 Mark Cornwall has found that of the seventy soldiers who crossed the line with Pivko in September I9I 7, most were either Serb or Czech. Mark Cornwall, The Undermining of Austria-Hungary: The Battle for Hearts and Minds (Basingstoke: Macmillan, 2000), I33.

6 Vladimir Ćorović, Crna knjiga patnje Srba Bosne i Hercegovine za vreme svjetskog rata (Belgrade: I. Đ. Đurđević, 1920), and Pero Slijepčević, 'Bosna i Hercegovina u svetskom ratu', in Napor Bosne $i$ Hercegovine za oslobođenje i ujedinjenje (Sarajevo: Izdanje Oblasnog odbora Narodne odbrane, I929).

7 Gunther E. Rothenberg, The Army of Francis Joseph (West Lafayette, IN: Purdue University Press, I976), I96. 
course of the war, some 80 per cent were from the countryside, that is to say, peasant conscripts. $^{8}$

Writing about the attitudes of these 'rank and file' soldiers in Russia and their response to the revolutions is difficult, since they are not as historically visible as, say, their officer counterparts. Yugoslav historiography since the Second World War, as well as memoir literature (and even novels and films), has tended to emphasise in the first place the number of South Slav soldiers who converted to communism before, during or immediately after October I9I7 (including, of course, Josip Broz 'Tito', who had served as a non-commissioned officer in the Habsburg army). ${ }^{9}$ It is true that a significant number of South Slav POWs were gravitating towards socialism in the period after the February revolution and before the Bolshevik coup. Within the South Slav volunteer division at Odessa, for example, a sizeable number of soldiers had broken away from their commanding officers and created a 'dissident movement' (in March I9I 7) numbering I 2,74 I soldiers (and I 49 officers). ${ }^{10}$ These soldiers formed well-organised councils and agitated for socialist revolution, and included a number of future luminaries of the Communist Party of Yugoslavia, such as Nikola Grulovic, Nikola Kovačević and Vladimir Ćopić. Tito, a prisoner of war (POW) in Russia at this time (although not associated with the volunteer movement), should also be included in a small but noteworthy list of South Slavs who became committed, life-long communists after spending time in revolutionary Russia.

The transformations in Russia at this time meant that Austria-Hungary would now face a costly 'aftershock' of the r9i6 Brusilov Offensive. All POWs in Russia were freed by the Bolsheviks at the time of the revolution, including thousands of South Slavs captured during Brusilov's assault. From the beginning of spring I9I 8 these former soldiers started to arrive home, if not died-in-the-wool Bolsheviks, then certainly unwilling to be re-mobilised into the imperial army. The actions of these returnees were ultimately fatal to Austro-Hungarian authority in the region, and contributed to an eruption of disorder and paramilitary violence towards the end of I9I 8 .

Nevertheless, the impact of the October Revolution in the region was not immediate. Perhaps in the light of the unexpected Austro-Hungarian military success in Caparetto towards in autumn I9I 7, reports from local authorities on the incidences of resistance in the monarchy's South Slav lands at the end of I9I7 found nothing

8 Ivo Banac, 'South Slav Prisoners of War in Revolutionary Russia', in Peter Pastor and Samuel R. Williamson Jr, eds., War and Society in East Central Europe, Vol. 5, Origins and Prisoners of War (New York: Brooklyn College Press, I983), I20.

9 On this topic see Banac, 'South Slav Prisoners'; Ferdo Čulinović, Odjeci Oktobra u jugoslavenskim krajevima (Zagreb: Izdavačko poduzeće 27. Srpanj, I957); Nikola Grulović, Jugosloveni u ratu $i$ Oktobarskoj revoluciji (Belgrade: Prosveta, I962); Ivan Očak, U borbi za ideje Oktobra: jugoslavenski povratnici iz sovjetske Rusije (1918-1921) (Zagreb: Stvarnost,1976); Očak, Jugoslavenski oktobarci: likovi i sudbine (Zagreb: Školske knjiga, I979); Očak, Barabaš (Zagreb: Kajkavsko spravišče, I978); Očak, Vojnik revolucije: život i rad Vladimira Ćopića (Zagreb: Spektar, I980).

10 Banac, 'South Slav Prisoners', I 3 I. 
worth noting. ${ }^{11}$ Imperial authorities, although strained, were still in control of the situation. But in February I9 8 a naval mutiny involving Czech and South Slav sailors broke out on ships stationed at the Bay of Kotor (Cattaro). ${ }^{12}$ Close on the heels of the sailors' revolt came the return of POWs from revolutionary Russia, beginning in March I9I8. Nervous Austro-Hungarian authorities, concerned about a 'red wave' of Bolshevik agitation coming out of Russia, interned these 'returnees' as soon as they crossed the monarchy's frontiers, and held them in special screening camps. The desire to end the war on the part of these men proved difficult to isolate and contain, however. Soldiers who were returned to their units often had a corrosive effect on morale, agitating for an immediate end to the fighting. Such agitation resulted in more revolts in spring, this time at barracks in Styria (Judenburg) and Herzegovina (Mostar). ${ }^{13}$

Many soldiers coming home from Russia simply refused to re-enlist in their regiments. They had a very simple message for their fellow countrymen about what they had seen during the revolution, as one peasant testified:

A soldier who returned from Russian captivity explained to us what the situation was in Russia. He told us how the Tsar treated the people, how the people put down their weapons, fed up with war and poverty ... they told us how revolution had destroyed the old order and how the people had decided that there would be no more war. They told us how the peasants and the workers were now the rulers of Russia, and that there was no more war over there. ${ }^{14}$

It was this sort of attitude that provided the catalyst for the disorder which engulfed the Croatian countryside in autumn I9I8. The promise of 'no more war', brought back from Russia by soldiers who had witnessed the revolution there, motivated many peasants to join armed bands, or 'Green Cadres' in the Croatian countryside. ${ }^{15}$ As Richard Plaschka has noted in his discussion of conflicting ideological currents in the Habsburg army during the war, Bolshevism appealed to soldiers first and foremost because it promised to establish the socio-political conditions necessary to end the exhaustion and material need caused by the war. ${ }^{16}$ Essentially, it promised to end the war.

11 Croatian State Archives, Zagreb (Hrvatski državni arhiv, hereafter HDA), fond 78. 'Predsedništvo Zemalske vlade', box 923 , no. 5868 .

12 Čulinović, Odjeci, I 88-243; Richard Georg Plaschka, Cattaro-Prag, Revolt und Revolution: Kriegsmarine und Heer Österreich-Ungarns im Feuer der Aufstandsbewegungen vom 1. Februar und 28. Oktober 1918 (Graz: H. Böhluas Nachf, I963); Rothenberg, The Army of Francis Joseph, 2 I I; Bernard Stulli, Revolucionarni pokreti mornara 1918 (Zagreb: Institut za historiju radničkog pokreta, I968).

13 Z. A. . Zeman, The Break-up of the Habsburg Empire 1914-1918: A Study in National and Social Revolution (London: Oxford University Press, I96I), I43, I63.

14 Čulinović, Odjeci, Io8.

15 On the Green Cadres see Ivo Banac, “Emperor Karl has become a Comitadji”: The Croatian Disturbances of Autumn I9I 8', Slavonic and Eastern European Review, 70, 2 (I992), 284-305; Culinović, Odjeci, 9I-I30; Bogdan Krizman, Raspad Austro-Ugarske i stvaranje jugoslavenske države (Zagreb: Školska knjiga, I977). For an interpretation of the disorder in the countryside at this time which dramatically de-emphasises the scale and organisation of the Green Cadres, see Dinko Čutura, 'Hrvatske postrojbe u Prvom svjetskom ratu i vojni raspad Austro-Ugarske', master's thesis, University of Zagreb, 2003.

16 Richard Plaschka, 'Contradicting Ideologies: The Pressure of Ideological Conflicts in the AustroHungarian Army of World War One', in Robert A. Kann, Béla K. Király and Paul S. Fichtner, eds., 
Variations on the theme of 'no more war' can be found in reports from local authorities in the monarchy's South Slav lands throughout I9I8. In Zemun in July, for example, authorities reported on an encounter with a returnee who promised that 'of all those returning from Russian captivity, not a single [soldier] will fight on the front, whichever front that may be'. ${ }^{17}$ In August, a peasant reported to authorities in Osijek (Slavonia) on a meeting he had had with two armed members of the Green Cadres. The men told him they were preparing a popular revolution similar to that in Russia, and assured him they had the weapons and the numbers to do so. ${ }^{18}$

\section{The National Council and the passage out of empire}

When, in October I9I8, the National Council of Serbs, Croats and Slovenes was formed in Zagreb, ${ }^{19}$ the monarchy had already lost de facto control of the region. However, the establishment of the National Council did not automatically create a new source of legitimacy in the region. This was because the politicians and intellectuals on the National Council were not at the vanguard of a popular revolution. In terms of numbers and weapons, the deserters, returnees and peasants who comprised the Green Cadres dwarfed the meagre forces of the National Council.

What, then, did these paramilitary groups want? Deserters and returnees, as we have seen, wanted to opt out of fighting the war, that is to say, to avoid re-enlistment. But by autumn I9I 8 this reluctance to fight on the part of peasants - the spark which ignited the disorder - appears to have assumed a broader social revolutionary platform, and was often directed at vestiges of the Habsburg ancien régime, and even at authority per se. Targets of the Green Cadres included members of the nobility, bureaucrats and large estates. ${ }^{20}$ The impotence of the National Council in the face of this violence is reflected in the pronouncements and decisions taken during its short lifespan. On the 29 October, for example, the day the Croatian Sabor severed all links with the Habsburgs, the National Council also issued a plea to soldiers formerly of the Austro-Hungarian army and the Green Cadres to submit to its authority and to stop the destruction of property: 'Don't destroy, don't burn down, don't kill, since you are destroying and burning that which is yours, soldiers!'21 Apparently in response to attacks on large landholdings, the National Council even discussed and then issued a proclamation promising a 'democratic agrarian-political reform' which would liquidate the vestiges of feudalism in the Habsburg South Slav lands and would redistribute land to the 'broadest layers of the agricultural population'.22 (In the event,

The Habsburg Empire in World War One: Essays on the Intellectual, Military, Political, and Economic Aspects of the Habsburg War Effort (New York: Boulder, Columbia University Press, I977), I06-7.

17 HDA, fond I363 'Politička situacija', box 3.

18 Ibid. See also Banac, "Emperor Karl has become a Comitadji”,

19 Ferdo Šišić, Dokumenti o postanku Kraljevine Srba, Hrvata, i Slovenaca: 1914-1919 (Zagreb: Matica hrvatska: I920), I70.

20 Banac, "Emperor Karl has become a Comitadji",

21 Šišić, Documenti, 2 I I.

22 Ibid, 257. Selections of documents produced by the various departments of the National Council have been published in the following volumes: Narodno vijeće Slovenaca, Hrvata, i Srba u Zagrebu 1918-1919: Izabrani dokumenti, chosen and arranged by Marina Štambuk-Škalić and Zlatko Matijević (Zagreb: 
the issue of agrarian reform in Yugoslavia was not fully resolved even at the end of the inter-war period.)

Even in Zagreb there existed resistance to the National Council. Just as the experience of war had altered depending on when and where soldiers had fought and which rank they held, the breakdown of military discipline and declining imperial and rising national loyalties were not uniform among South Slavs. On the Italian Front, for example, the crises of the hinterland corroded South Slav soldiers' reliability and willingness to fight for the monarchy more slowly than on other fronts. ${ }^{23}$ Stjepan Sarkotic remained loyal to Austria-Hungary and its war effort until he received orders directly from the Ministry of War in Vienna to hand over his troops to the Bosnian National Council. ${ }^{24}$ Similarly, two Habsburg generals of Croat descent, Luka Šnjarić and Mihovil Mihaljević, were unwilling to put themselves and their forces at the disposal of the National Council until they had received instructions to do so from Emperor Karl himself, at Schönbrunn palace. ${ }^{25}$

The changing state of imperial and national loyalties of men such as Sarkotic, Šnjarić, Mihaljević et al., not to mention the more immediate problem of the Green Cadres, created an atmosphere of high tension in the National Council. For example, the council ordered the train carrying Sarkotic to Zagreb in November I9I 8 to be surrounded with armed guards. Uncertain as to what the general's intentions in the capital were, they detained him for ten days before letting him go into self-imposed exile, initially to Graz. ${ }^{26}$ In similar fashion, the National Council panicked when learning of the return to Zagreb of Antun Lipošćak, the former governor-general of occupied Poland. It was not convinced by the general's note of I 2 November, welcoming the creation of 'Great Yugoslavia' and offering to put his soldiers at the disposal of the National Council. ${ }^{27}$ It was believed instead that he intended, along with a group of fellow officer co-conspirators, to overthrow the new regime in Zagreb and replace it with a military dictatorship. The National Council arrested Lipošćak and a fellow conspirator on the night of 22 November, announcing the next day that they had thwarted a plot involving ex-Habsburg officers throughout the country. ${ }^{28}$

The 'Lipošcak Affair' also provided a pretext for the leading Croatian Serb politician in the National Council, Svetozar Pribićevic, to press for unification with the Kingdom of Serbia and with Montenegro (that is to say, to create Yugoslavia), and to invite the Serbian army into the former Habsburg lands. ${ }^{29}$ The decision, taken on the night of 24-25 November, was supported by an overwhelming majority in the National Council, concerned with peasant unrest, pro-Habsburg elements and Italian

Hrvatski državniarhiv, 2008), and Milan Pojić, ed., Vjesnik naredaba Odjela za narodnu obranu Vlade Narodnog vijeća Slovenaca, Hrvata, i Srba 1918-1919 (Zagreb: Hrvatski državniarhiv, 2008).

23 Cornwall, Undermining Austria-Hungary, 287-298.

24 Noel Malcolm, Bosnia: A Short History (London: Pan, I996), I62.

25 Ferdo Čulinović, Jugoslavija izmedju dva rata, 2 vols. (Zagreb: Jugoslovenska akadamija znanosti i umetnosti, I96I), 68-9.

26 Obzor, 8 November I9I 8.

27 HDA, fond I24,'Narodno viječe SHS: Sekcija za organizaciju i agitaciju', opči spisi, box 9.

28 Obzor, Is February i9i9.

29 Tomislav Zorko, 'Afera Lipošćak', Časpois za suvremenu povijest, 35 (2003), 896. 
designs on the Adriatic littoral. ${ }^{30}$ Significantly, it was opposed by Croatian People's Peasant Party leader Stjepan Radić, ${ }^{31}$ as well as by the pro-Habsburg 'Frankists', the party which had organised anti-Serb riots after the Sarajevo attentat in I9I $4 .{ }^{32}$

\section{The Serbian army in the former Habsburg lands}

The Serbian army, on the back of liberating Serbia from Austro-Hungarian and Bulgarian occupation, came to fill the power vacuum created by the disintegration of Austro-Hungarian control of the region. Again, the different histories of the Habsburg lands during the war inform the different responses to this event throughout the Habsburg South Slav lands. For Bosnian Serbs, who had been out of favour during the war, the Serbian army was considered an army of liberation, just as it had been in Serbia. Less well-disposed towards the entrance of the army was the Mulsim population of Bosnia and Herzegovina, targeted on account of their collaboration, real or perceived, with the wartime regime. Peasant unrest similar to that seen in Croatia and Slavonia assumed predominantly national contours, as Serb peasants attacked Muslim landholders throughout the country. ${ }^{33}$ This violence persisted after unification. In July I920, for example, Bosnian Muslim leaders staged a rally complaining that attacks on the Muslim population continued in the new state, and that perpetrators of this violence had gone unpunished. ${ }^{34}$ But in Dalmatia, under the same wartime occupation as Bosnia, the Serbian army was, at least initially, welcomed by a large part of the population. ${ }^{35}$ Here, wartime hardship combined with the real threat of Italian expansion, generated a pro-unitarist, pro-Yugoslav sentiment.

The most important zone of conflict and resistance to the Serbian army and its efforts to gain control in the former Habsburg lands was the Croatian hinterland. Two factors are crucial in this region. First, and most importantly, are the changes in attitudes among the Croatian peasantry towards authority and centralised rule as a result of the war and the deterioration and demise of the Habsburg empire. In this sense, the period should be considered in terms of a process which began with the degradation of Habsburg authority in spring I9I 8 and continued with the entrance of the Serbian army at the end of the year. The new regime was struggling to impose obligations on Croatian peasants, especially paying taxes and serving in the army, which, as a result of the fall of the monarchy, came to be considered to be nonbinding. Second, and a corollary of this first point, are the attempts to capitalise on

30 Bogdan Krizman, Hrvatska u prvom svjetskom ratu: Hrvatsko-srpski politički odnosi (Zagreb: Globus, I989), 34I-5I.

31 Stjepan Radić, 'Govor na noćnoj sjednici Narodnog vijeća (u Zagrebu, 24. I I. I9I 8)', in Stjepan Radić: Politicki spisi, govori, i dokumenti (Zagreb: Znanje, I995), 79-86.

32 The Frankists distributed leaflets after the unification (I December) claiming that the National Council had acted without the blessing of the Croatian people. See Čulinović, Jugoslavija između dva rata, I, I $57-9$.

33 Ivo Banac, The National Question in Yugoslavia: Origins, History, and Politics (Ithaca: Cornell University Press, I988), 367.

34 Archive of Yugoslavia (Arhiv Jugoslavije), Fond I4 'Ministarstvo unutrašnjih poslova', facsimile 4, no. I4.

35 Henry Baerlein, The Birth of Yugoslavia, Vol. 2 (London: Leonard Parsons, I922), 35. 
this continued mood of resistance to authority by two groups: the small vanguard of Bolshevik 'returnees' and their unsuccessful attempts to effect a socialist revolution in the countryside, and the Croatian Peasant Party of Stjepan Radic, who, with far greater success, encouraged pacifist resistance and non-compliance towards the new regime.

\section{Regaining control in Croatia}

Sources suggest that in Croatia the Serbian army quickly came to be perceived by the local population as an occupying force. As the American observer Leroy King warned in spring I9I9, "The Serbian army is now scattered throughout Croatia; and there have been many acts of "militarism" which the peasants do not like. Here in Agram [Zagreb] one hears many expressions of dislike for the methods of the Serbian military administration. ${ }^{\prime 36}$ The potential for unrest among the Croatian peasantry continued to be noted by the authorities. In August I920, for example, a circular was despatched from Zagreb throughout Croatia and Slavonia warning of the deterioration of public security in Slavonia (especially Srijem) over the previous four to five months. ${ }^{37}$ The circular advised the recruitment of local leaders, clergy and school teachers in a bid to impress upon the population of these areas the need for improved security, which was, after all, in the interests of everyone. ${ }^{38}$

In the official government and police records of the time the spectre of communism looms large over the Croatian countryside. Here Yugoslav authorities shared the concerns of their Habsburg predecessors. In June I9I9, for example, the gendarmerie chief reported that soldiers returning from Russian captivity were spreading Bolshevism in the district and that in nearby Crkvenici, a similar 'republican spirit' had been observed. ${ }^{39}$ In the army, short-lived revolts took place in barracks in Maribor and Varaždin (22 and 23 July I9I9 respectively). In Varaždin, the rebels issued demands for a republic and for a 'Yugoslav People's Army'. ${ }^{40}$ There were reports of a similar attempt at 'Bolshevik insurrection' in Osijek, which appeared to have support from Béla Kun's Hungary. According to the authorities, it was a belief in the arrival of 'Red Guards' from Hungary which had provoked the uprising, rather than dissatisfaction with pay or living standards among soldiers. ${ }^{41}$ In Karlovac, also in summer I9I9, a commanding officer reported similar conditions in his battalion. A group of ex-POWs were agitating among conscripts in order to spread Bolshevism; he believed that conscripts would take heed of Bolshevik propaganda merely to escape from their military duties. It was because of this unwillingness to serve in the army, he felt, rather than for any ideological reasons, that Bolshevism presented a threat. ${ }^{42}$ This

\footnotetext{
36 'Leroy King's Reports from Croatia March-May I9I9', Journal of Croatian Studies, I (I960), 85.

37 HDA, fond I 363 , 'Politička situacija', box 6.

38 Ibid.

39 Ibid.

40 Stanislava Koprivica-Ostrić, 'Vojnička pobuna u Varaždinu 23. VII I9I9. godine', Časopis za suvremennu povijest, 25 (I983), 85 .

41 HDA, fond 78 'Predsjedništvo zemalske vlade I869-I92 I', box 960.

42 Ibid.
} 
last point is of critical importance. The Yugoslav authorities were essentially facing the same problem as the Habsburg authorities before them, albeit in very different circumstances. After I9I 8 , just as before, hostility to centralised authority per se and protest against material hardship were the motivating factors for resistance, rather than strong ideological convictions among the peasantry.

This is not to say that the Bolshevik threat was entirely a fantasy. A small but well-organised vanguard comprising ex-soldiers (Serbs, Croats and Slovenes) worked energetically in the period after the war to establish a Bolshevik party and network for the purpose of socialist revolution, and their activities have been well documented in the historiography. ${ }^{43}$ Ex-soldiers such as these found transnational allies and financial backers in Béla Kun's short-lived Hungarian Soviet in I9 I9, ${ }^{44}$ and communists across the country were successful in organising a national strike, also in I9I9 (June). Communism emerged as a movement with countrywide support in the elections to the constitutional assembly in November 1920 (the only party with significant support among more than one national group), having already received a majority in municipal elections in Zagreb and in Belgrade, the two most important cities in Yugoslavia. ${ }^{45}$

However, support for communism in the Croatian countryside was more circumscribed than the authorities imagined. Exhaustion and an increasing unwillingness to take up arms, part of the legacy of the war, meant that Bolshevik 'returnees' were swimming against the post-war tide at this time. Of far greater resonance was Stjepan Radić's pacifist, anti-militarist message, encouraging peasants to resist the new regime, just as they had the old. Radic appealed to peasants by associating Yugoslavia with Austria-Hungary; both regimes had inflicted taxes and conscription on the Croatian peasant. He interpreted the 'occupation' of the Croatian countryside by the Serbian army at the end of I9I 8 as a return to the kind of militarism which had been thoroughly discredited in the violence unleashed by the war. ${ }^{46}$ Impressed by the threat of international communism, its successes elsewhere in central Europe and the memory of the role played by 'returnees' in the Green Cadres, the authorities were unable, or unwilling, to draw a clear distinction between Radićs anti-militarist message and Bolshevism. The two terms are often used interchangeably in the sources, as has been shown. Peasant violence and resistance in the Croatian countryside, then, peaked in the last days of the war and then subsided (but did not disappear) with the end of the war and the arrival of the Serbian army. Unrest here was closely linked to peasant attitudes towards centralised authority, a relationship that

43 Ivan Očak, 'Povratnici iz sovjetske Rusije u borbi za stvaranje ilegalnih komunističkih organizacija uoči prvog kongresa SRPJ (k)', Historijski zbornik, XXVII (I974-5), I-26; also Ivo Banac, 'The Communist Party of Yugoslavia During the Period of Legality I9I9-I92I', in Bela K. Kiraly, ed., War and Society in East Central Europe, Vol. I 3: The Effects of the World War One: The Rise of Communist Parties (New York: Brooklyn College Press), i 88-2 I2.

44 Ivan Ramljak, 'Afera Diamenstein', in Zdravko Dražina, ed., Zagreb jučer, danas, sutra (Zagreb: Epoha, I965), 207-I7.

45 Results of the elections for the constituent assembly are given in Banac, National Question, 388-9.

46 Ivan Mužić, Stjepan Radić u Kraljevini Srba, Hrvata, i Slovenaca (Zagreb: Hrvatske književno društvo sv. Ćirila i Metoda, I987) 39. 
had transformed dramatically as a result of the war. It was precisely this unwillingness to co-operate with Habsburg authorities which led to an unwillingness to co-operate with Yugoslav authorities after I9I 8.

\section{The Croatian counter-revolution}

Paradoxically, it was a continued commitment to wartime goals that led to a small group of ex-Habsburg officers and 'Frankists' to organise an unsuccessful rebellion against Yugoslavia in the same period. We have seen that the National Council in Zagreb was anxious about a Kornilov-style military coup at the end of the war, taking no chances with returning generals such as Sarkotić and Lipošćak. In fact, outside observers had also warned that ex-Habsburg officers of Croat descent such as these might try to resist the new order, especially after unification with Serbia and Montenegro on I December. The US lieutenant Leroy King and the British major Arthur Temperley, both in Zagreb in spring I9I9, reported as such to their respective governments. Under the heading 'The Reactionaries and Discontented', King placed 'ex-officers of the Austrian army (Yugoslavs by blood) who have been retired because of their leanings to the old regime', adding that such officers 'spread pessimism and are ready to urge discontent'.$^{47}$

I can imagine what the ex-Austrian officers, who glare at one from the cafes, must say about the Serbs. This growing unpopularity of the Serbian army will easily be transformed into dislike of the Serbian people and influence. It is a dislike which already exists to some extent, and Major Temperley agrees with me in thinking it a real danger. ${ }^{48}$

For his part, Major Temperley counted thirty-six retired generals and ' 500 staff or field officers' in the neighbourhood of Zagreb, and concluded that 'generally speaking the officers are a more active body of discontented persons than the nobles'. ${ }^{49}$

Indeed, a plot involving ex-Habsburg officers and Frankist émigrés and the formation of a 'Croatian Committee' and a 'Croatian Legion' were eventually uncovered by Yugoslav authorities over the course of I9I9-20. The exact details of this plot are still unclear. ${ }^{50}$ The Croatian Committee was established in summer I9I9 precisely for the purpose of effecting the kind of anti-Yugoslav revolution the authorities feared. The Croatian Committee was a paramilitary group, or at least aspired to be a paramilitary group, comprising ex-Habsburg officers and POWs (from Italian captivity) and based, eventually, in Miklós Horthy's Hungary. According to one source, the Croatian Committee started out as a propaganda council, with the intention of calling for the withdrawal of the Serbian army from Croatia, followed by free elections. This course of action had been decided in Austria at

47 'Leroy King's Reports', 83-4.

48 Ibid., 85 .

49 The National Archive, Kew (TNA), PRO/FO37I/3508, 'The Political Situation in Croatia - 3 Ist March i9i9'.

50 Banac, National Question, 264, and Bosiljka Janjatović, Politicki terror u Hrvatskoj 1918-1935 (Zagreb: Hrvatski institut za povijest, 2002) I96. 
some point in I9I9, following a meeting between several ex-Habsburg officers. ${ }^{51}$ These émigrés maintained contacts with Habsburg legitimists in Hungary and with the Italian ambassador in Vienna, ${ }^{52}$ both parties having an interest in using the Croats to undermine the new Yugoslav regime.

The formation of a Croatian Legion, a volunteer force based in Hungary (Koszeg, and then later Zalaegerszeg), was announced by the Committee in November I9I9..$^{53}$ Its chief recruiter was Stipe Duić, a former lieutenant-colonel in the monarchy's army and a Habsburg legitimist. ${ }^{54} \mathrm{He}$ was allowed by the Italian government to tour their POW camps garnering support for the Committee's cause. ${ }^{55}$ In their propaganda the committee boasted of 300,000 soldiers, although this was certainly an exaggeration designed to boost support. ${ }^{56}$ The authorities in Belgrade and in Zagreb were aware of the activities of the two bodies from a very early stage..$^{57}$ They supplied a figure derived from 'various sources' of 250 officers, with a further fifty 'higher officers', also noting the support of Hungarian legitimists and the existence of a spy network in Vojvodina (Novi Sad). ${ }^{58}$ In a letter addressed to a Croatian Peasant Party deputy, Vladko Maček, and reprinted in Belgrade's Politika newspaper, Vladimir Sachs, a Croatian Committee member and Frankist, suggested that the actual total was nearer to Ioo men. ${ }^{59}$

Presuming that Sachs's figure is closest to the truth, the Croatian paramilitary counter-revolution was far smaller than its counterparts in Hungary, Austria and Germany. It seems likely that these émigrés were counting on a number of other factors which might offset their lack of manpower, a consideration which has thus far not been noted in the historiography of the legion. Widespread discontent in Croatia at the unification was taken for granted by the émigrés. More specifically, it was felt that disgruntled Croatian officers and soldiers serving in the newly formed Yugoslav army would support any putative uprising against the Serbs (this assumption was made repeatedly by the Croatian radical right in the inter-war period).

Even more important for this group of officers and would-be militants was the example set by other paramilitary groups in Europe, such as the Freikorps in Germany, Gabriel D’Annunzio's volunteer army in Fiume (Rijeka), the Szeged counter-revolutionaries in Hungary and the Austrian Heimwehr. For each of these groups the armistice of I9I 8 marked a new stage in the war, rather than its cessation. They provided a context and a precedent for the Croatian émigrés, and examples of the Croatian Committee seeking allies or co-operating with like-minded parties

51 According to the account of committee member turned Yugoslav police informant Emanuel Gagliardi, Istina o hrvatskom emigrantskom revolucionarnom komitetu 1919-1921 (n.p., I922).

52 Vuk Vinaver, Jugoslavija i Mađarska 1918-1933 (Belgrade: Institut za savremenu istoriju, I97I), I20.

53 Banac, National Question, 264.

${ }^{54}$ For information on Duić see Stjepan Matković, 'Životopis časnika Stjepana Duića (II.)', Politički zatvorenik, no. I46, May 2009.

55 HDA, fond I363, 'Politička situacija' box 5 .

56 Banac, National Question, 264.

57 HDA, Fond I 363 Politička situacija' box 5 .

58 Ibid.

59 TNA, PRO/FO 37I/6I94. 
among these groups have been well documented. ${ }^{60}$ The émigrés of the Croatian Committee and the Croatian Legion saw themselves as part of this "paramilitary subculture' 61 in central Europe, and it was as part of this potent subculture that they saw their greatest chance of success. Moreover, like the ex-soldiers of the Freikorps and the Heimwehr, the war veterans of the Croatian Committee believed that defeat and collapse in war could be redeemed through violence and resistance to the new order.

\section{The regional context}

Having considered the various paths of soldiers, officers and peasants out of empire and into Yugoslavia, it is now possible to integrate this interpretation of violence, revolution and counter-revolution in Croatia into a regional framework. Clearly, the violence and unrest in the region during I9I7-I923 belong in a central European context,${ }^{62}$ the demise of Austro-Hungarian authority from the beginning of I9I 8 onwards impacting also on Hungary, Austria, Transylvania, the Bohemian lands and so on. Rural unrest was also present in Hungary and in Germany during the period. The crucial role of 'returnee' soldiers from Russia in the nascent Communist Party of Yugoslavia points to a more general regional phenomenon; ${ }^{63}$ indeed, one such returnee, Béla Kun, was able to install (briefly) a revolutionary regime in Hungary, an achievement which Yugoslav communists unsuccessfully attempted to emulate, as we have seen. The émigré ex-officers who gravitated towards the Croatian Legion saw themselves as part of the European counter-revolution after I9I 8, the 'White International' responsible for so much paramilitary violence during the period. Unlike their counterparts in Hungary, Austria and Germany, however, they lacked the numbers and the political support to become a real force. The Croatian counter-revolution relied on the support of larger paramilitary groups and foreign political sponsorship (most importantly Italy), and counted on an as yet unproven revolutionary mood among the people in Croatia. In fact, the émigré officers were in a minority already, thanks to the (qualified) success of the new Yugoslav army in integrating ex-Habsburg officers into its ranks. Many career soldiers were willing to swap the Habsburg double-headed eagle for that of Karađorđević, leaving behind a smaller group of unreconciled officers such as Duić and Sarkotić. ${ }^{64}$

60 The Interior Ministry in Belgrade reported that a number of former officers of Croatian descent were receiving food and equipment from Budapest, and that Andrassy planned to use Croatian officers in an attempt to restore Charles to the throne in Hungary. See Mira Kolar Dimitrijević, 'Lomljene višestoljetnih veza između Hrvatske i Mađarske nakon prvog svjetskog rata', Historijski zbornik, 47 (I995), I34-5.

61 Robert Gerwarth, 'The Central European Counter-Revolution: Paramilitary Violence in Germany, Austria, and Hungary after the Great War', Past and Present, 200 (August 2008), I98.

62 The definition of central Europe and the categories of revolution in the following discussion are taken from Tibor Hajdu, 'Socialist Revolution in Central Europe, I9I7-I92 I', in Roy Porter and Mikuláš Teich, eds., Revolution in History (Cambridge University Press, I986), IOI-I9.

63 Kiraly, War and Society.

64 On the process of creating a Yugoslav army after the war see Mile Bjelajac, Vojska kraljevine Srba, Hrvata, i Slovenaca 1918-1921 (Belgrade: Narodna knjiga, I988). See also Hrvoje Čapo, 'Broj primljenih časnika 
This last point starts to answer the question as to why there was no Red/White convulsion here as there was in other parts of central Europe. A socialist revolution, such as that which established the Hungarian Soviet, must have seemed more likely. Communism after I9I 8 had electoral support in important urban centres, including Zagreb and Belgrade (although communist mandates were quickly annulled in these municipalities), and mass support, of a kind, in Macedonia and Montenegro. ${ }^{65}$ Professional revolutionaries returning from Russia could have tapped into the discontent and anti-war sentiment among the Croatian peasantry just as the Bolsheviks had done in Russia; this too would have made them a force to be reckoned with.

There are two important reasons why the communists failed in Croatia where their comrades in Hungary and Germany had succeeded. Firstly, and crucially, was the unexpected transformation of the Croatian People's Peasant Party, under Stjepan Radic, from a small faction in the Sabor into a mass movement, a transformation which was all but complete by the time of the 1923 national elections in Yugoslavia. ${ }^{66}$ Crucially, Radićs programme of agrarian populism, which enjoyed the complete support of the Croatian peasantry until his death in I928, rejected any kind of revolutionary move against the authorities. Although Radic came to reject (like the communists) the centralised Yugoslav state and was extremely critical of the Serbian army's presence in Croatia, his trenchant anti-militarism (a tenet of his programme which he claimed was informed by the unhappy experience of Croatian soldiers during the war) prohibited any potentially violent uprising. As he himself put it, talking about the October Revolution,

There were more than I00,000 of our people in Russia, and they saw what the greatest world revolution really was. They understood its spirit, namely, that a free peasantry be created. They supported this spirit of freedom, but they condemned the methods. ${ }^{67}$

The mass appeal of Radić's Peasant Party cut the communists off from grass-roots support in the countryside, support that they would have needed to take power.

Closer study of the reasons for the popularity of communism in Yugoslavia at the end of the First World War can also help to explain its failure to gain a foothold in Croatia. The communists' biggest electoral successes in the elections to the Constituent Assembly in November 1920 were in Macedonia and Montenegro. But in these regions, it seems, communist strength was due more to protest voting against the new regime than to ideological affinity and support for socialist revolution. But there was no Radic or any popular peasant movement in these regions. Anti-regime voters had nowhere else to turn, whereas in Croatia Radić's defiant attitude towards Belgrade provided an outlet for ex-soldiers and peasants whose impulse was to resist central authority.

bivše austrougarske vojske u vojsku Kraljevine Srba, Hrvata i Slovenaca', Časopis za suvremenu povijest, 3 (2008), I087-103.

65 On the electoral strength of the communists in Yugoslavia in the elections of November I920, see Banac, National Question, 33 I.

66 On Radic and the Peasant Party see Mark Biondich, Stjepan Radic, the Croat Peasant Party, and the Politics of Mass Mobilization, 1904-1928 (Toronto: University of Toronto Press, 2000).

67 Cited in ibid., I60. 
There still remains the striking contrast between Hungary's brief Bolshevik revolution and Croatia's national/pacifist turn. Why did Hungarian returnees from Russia find the idea of a socialist revolution more palatable than their Croatian counterparts? Of course, Hungary lacked a popular agrarian movement akin to that of the Croatian Peasant Party. Whether the existence of such a movement would have altered the course of Hungary's post-war history is a matter of speculation. Tibor Hajdu, in his comparative study of central European socialist revolutions during I9 I 723, has noted the dominant role played by Vienna and Budapest in the Austrian and Hungarian cases. ${ }^{68}$ Miklós Horthy himself acknowledged the importance of 'sinful Budapest' in directing the Hungarian Bolshevik revolution. The same relationship of dominance and suppression did not exist between Zagreb and the Croatian countryside. On the contrary, the latter led the former, as the history of the National Council shows. The popularity of communism in Zagreb was eclipsed by the peasant movement in the countryside.

Furthermore, the communists were almost eradicated by extremely effective policing and legal measures taken against them in the period immediately after the war. The fear of a 'red wave' coming from revolutionary Russia, as well as a more general sense that unification was under threat in the years after I9I 8, helped pass the Obznana (Decree) restricting the activities of the Communist Party of Yugoslavia. The communists themselves then provoked 'The Law for the Protection of the State' (Zakon Zaštite države, ZZD) which criminalised the party altogether, after they assassinated a former interior minister Milorad Drašković (I92 I). Drašković, killed by a young communist from Bosnia named Alija Alijagić, was targeted since he had been instrumental in enforcing the Obznana. The success of the anti-communist legislation can be measured by looking at the party's membership numbers, which declined from 80,000 in December 1920 to just 688 in December I923, and never rose above 3,500 for the rest of the decade. ${ }^{69}$ As Christian Axboe Nielson has noted, the Obznana and the ZZD set important precedents for the heavily policed dictatorship of King Alexander (from I929 until I934), ${ }^{70}$ and the communists and Yugoslav authorities fought a twilight battle against each other for the rest of the inter-war period. ${ }^{71}$

\section{Conclusion: Yugoslavia after 1923 - a peaceable kingdom?}

Did the period I9I7-23 mark the beginning and the end of the violence and resistance associated with the demise of the empire and the transition of the region into a nation-state? It certainly seems that the combination of factors examined in this article contributed to establishing the centralised Yugoslav state of the I920s. The preponderant force of the Serbian army suppressed a countryside disorder whose key

68 Hajdu, 'Socialist Revolution', I I I.

69 Ivan Avakumović, History of the Communist Party of Yugoslavia (Aberdeen University Press, I964), I85.

70 Christian Axboe Nielson, 'Policing Yugoslavism: Surveillance, Denunciations, and Ideology during King Aleksandar's Dictatorship, I929-I934', East European Politics and Societies, 23, I (2009), 36-7.

71 For a first-hand account of this battle see Milovan Đilas, Memoir of a Revolutionary (New York: Harcourt Brace Jovanovich, I973). 
reason for protest became moot once the war ended. Radićs programme of pacifist resistance dampened further chances of unrest and also cut communists adrift from their vision of a popular revolution. Legislation designed to marginalise anti-Yugoslav or radical political organisations drove this movement underground. Finally, the passing of the high-water mark of counter-revolution in central Europe extinguished the chances of a paramilitary group of ex-officers too small to act alone with any chance of success, and the integration of career officers into the new army deprived the movement of more manpower. To all extents and purposes, violent resistance was pushed to the very fringes by the end of our period.

However, Yugoslavia was to experience some aftershocks of its own, which changed the fortunes of some of these groups. In 1928, following a heated dispute in the national parliament, a Montenegrin deputy named Puniša Račić, a veteran of the First World War, shot at deputies of the Croatian Peasant Party, killing three, including (eventually) Stjepan Radić. The resulting anger in Croatia against the regime in Belgrade shifted the centre of political gravity in the region and showed that currents present in I9I7-23 had been dormant rather than extinguished in the interim. The anti-militarism and pacifism of the Croatian Peasant Party became more qualified as the new leader, Vlatko Maček, provided for paramilitary units known as the Civil Guard (Građanska zaštita) and the Peasant Guard (Seljačka zaštita) to protect its members at party meetings. These formations comprised mainly former Habsburg officers. ${ }^{72}$

The instillation of King Aleksandar's royal dictatorship at the beginning of I929, promulgated following the months of parliamentary crisis brought on by the assassinations, also revived the fortunes of the Frankists and their ex-officer supporters. At some point during I929 a leading Frankist named Ante Pavelić and an ex-Habsburg officer named Gustav Perčec formed the Insurgent-Croatian Revolutionary Organisation (Ustaša-Hrvatska Revolucionarna Organizacija, UHRO, or simply the Ustashe). Analyses of this movement which emphasise the dialectical relationship of its violence with the terror and oppression of the dictatorship (especially in Croatia) ${ }^{73}$ are at risk of ignoring its important pre-history before I929. The small group of Frankists and ex-Habsburg officers who comprised the nucleus of the post-I929 Ustashe had pursued a radical course - one that did not exclude the use of violence or terrorism in order to gain Croatian independence from the very beginning of the I920s. In this sense, the Croatian Committee, with its paramilitary organisation, its ex-officer composition and its transnational network of allies that were almost identical to those of the Ustashe (Fascist Italy, Hungarian counter-revolutionaries, Macedonian autonomists) is an important prototype for the Ustashe of the I930s. The notion that ex-Habsburg officers were gathering to form an anti-Yugoslav paramilitary formation was a recurring concern of the authorities in the 1920 s $^{74}$

72 Sabrina P. Ramet, 'Vladko Maček and the Croatian Peasant Defence in the Kingdom of Yugoslavia', Contemporary European History, I6 (2007), I99-2 I3.

73 See, e.g., James J. Sadkovich, 'Terrorism in Croatia I929-34', East European Quarterly, 22, I (I988), 55-79.

74 HDA, Fond I 363 , 'Politička situacija', no. 808, a report from December I 923 in which a conversation is overheard in a Zagreb café between two men, one claiming that 'We have three thousand former 
Even more striking for its eerie anticipation of Ustasha terrorism is the report made by British intelligence in Austria and Yugoslavia in June 1922 concerning a plot to assassinate King Aleksandar at his wedding celebrations. The British claimed that the conspiracy involved the 'Party of Independence' (that is, the Croatian Party of Right, the Frankists) and was directed by a 'certain Hungarian Major, Stipetitch [Vilim Stipetić]. This man was the leader of the Croatian National Committee, which functioned in Vienna in I9 I9, afterwards moving to Graz and finally to Budapest.' The intended assassin for this operation was not a Croat, but a Macedonian autonomist, Marion Kilifarsky, recommended by the Bulgarian Macedonian Committee (Internal Macedonian Revolutionary Organisation, or VMRO), 'formerly a Comitadji', but now 'an independent desperado'. ${ }^{75}$ In other words, in its conception the operation foreshadowed the successful assassination of King Aleksander in Marseille in October I934, an action conceived and planned by Croatian separatists, but executed by a Macedonian gunman, leased to the Ustashe by VRMO. Future research into the Ustashe should not neglect the pre-I929 careers of the organisation's Frankist and ex-officer members, especially their activities during I9I7-I923.

Finally, the remnants of the Communist Party of Yugoslavia were well placed to endure the constraints of life under Aleksandar's dictatorship. Because of the ZZD they had been operating outside the law since I92I, and their tiny membership had become habituated to surveillance and suppression by the state. Joined in mutual opposition to the dictatorship, the communists actually formed a tactical alliance with the Ustashe, making a distinction between the 'fascist character' of the movement's leadership, and the 'progressive national-revolutionary character' of their few followers among the peasantry. ${ }^{76}$ It was a partnership which held until the late I930s, but was long forgotten by most by the time the communists faced the Ustashe in the Yugoslav Civil War of I94I-5.

The relatively less intense post-war, post-imperial violence in this region should not lead to the conclusion that the transition from empire to nation-state was, with a few hiccups, ultimately successful. Clearly, many of the groups examined in this article were not reconciled to the new order during I9I $7-23$, but were rather marginalised, often through the use of force. These marginalised groups nevertheless remained present throughout the inter-war period and were frequently able to undermine Yugoslavia, especially in the I930s. In order to understand the trajectory of inter-war Yugoslavia, it is better not to ignore the transformations and violence of I9I7-23.

officers organised, three well-prepared generals, ready to fight for independence'; ibid., no. I048, from January 1925, the Ministry of Interior claims that a group of ex-officers are making frequent trips to Austria for 'anti-state reasons'; ibid., no. I320, September I928, the Ministry of Interior cites 'reliable sources' that former Austro-Hungarian officers are organising, again for anti-state purposes; ibid., no. I744, April I929, the Ministry of Interior heard of a plot to make a revolution in Zagreb, conspirators are 'Austro-Hungarian officers' (this last is probably a reference to the Ustashe in exile, which Ante Pavelić was in the process of forming at the time).

75 NA, FO 37I, 7679-8097.

76 Aleksa Đilas, The Contested Country: Yugoslav Unity and Communist Revolution, 1919-1953 (Cambridge, MA: Harvard University Press, I99I), 96. 